\title{
Tumor infiltrating immune cells - potential powerful predictors in colorectal cancer patients
}

\author{
Stefan Riss, Rudolf Oehler \\ Medical University of Vienna, Department of General Surgery, Austria
}

Corresponding author: Stefan Riss, M.D., Medical University of Vienna, Department of Surgery, Währinger Gürtel 1820, A-1090 Vienna, Austria.

Tel: ++431404005621,Fax: ++431404006932.

E-mail: stefan.riss@meduniwien.ac.at

Received: $2011-10-13$

DOI : $10.5430 /$ jst.v1n3p87

\author{
Accepted: $2011-11-15$ \\ Published: 2011-11-23 \\ URL: http://dx.doi.org/10.5430/jst.v1n3p87
}

In the recent years, great effort was undertaken to elucidate prognostic markers after colorectal resection for malignancies. For example, tumor suppressor genes, DNA repair markers, markers for angiogenesis and several other potential parameters were intensively investigated. However, to date, present data do not provide sufficient evidence that warrants the majority of available prognostic markers to be used in daily clinical practice.

The primary goal is to define reliable parameters that could predict early relapse of cancer and reduced disease free survival in affected patients. Thus, individual risk stratification for each patient is the key stone to find out those patients who might benefit from a more intensive adjuvant treatment. On the other hand, those patients who have a considered low risk of disease recurrence may not require postoperative treatment modalities.

A number of studies focused on the prognostic value of immune cells that infiltrate colorectal cancer tissue. ${ }^{1-3}$ Notably, several studies reported quite impressive results, demonstrating a potential link between prognosis and response to chemotherapy and tumor infiltrating immune cells. Pagès, et al., observed that tumours with a high density of infiltrating CD45R0+ cells in combination with CD8+ cells were associated with a good clinical prognosis. ${ }^{4}$ Moreover, early metastatic invasion correlated with decreased levels of CD8+ T cells, ranging from early memory (CD45R0+CCR7CD28+CD27+) to effector memory (CD45R0+CCR7-CD28-CD27-) T cells. ${ }^{3}$ Increased levels of messenger RNA (mRNA) for products of type 1 helper effector $\mathrm{T}$ cells were also found to be associated with no signs of early metastatic invasion. Similar results were reported by the same working group, showing that the type (CD3, CD8, GZMB and CD45R0), density, and location of immune cells (invasive margins and center of tumor) were a better predictor of patient survival in comparison to common histopathological methods. ${ }^{1}$

Other reports underlined these findings by demonstrating positive correlation of tumour infiltrating immune cells and better prognosis. ${ }^{2}$ In contrast, there exist controversial data in regard to regulatory T cells. For example, Sinicrope, et al. reported an increase in intraepithelial FoxP3+ cells was correlated with poor tumour differentiation. ${ }^{5}$

Another point of interest refers to the type of administered chemotherapy. In the light of controversial data, it becomes increasingly important to define parameters that could predict the clinical response to chemotherapy. Thus, a tailored treatment for individual patients can be offered, providing maximal benefit for each patient on the one hand, and economic cost reduction on the other hand. Chemotherapy induced tumor cell death results in the release of tumorderived antigens as well as danger signals that could either be captured for triggering antitumor immune response or 
ignored. There is an impressive amount of data from animal models showing that the high mobility group box 1 protein (HMGB1) released by dying tumor cells after chemotherapy or radiotherapy interacts with Toll-like receptor 4 (TLR4) on DCs, which are selectively involved in the cross-priming of anti-tumor T lymphocytes in vivo. ${ }^{6} \mathrm{~A}$ recently published clinical study revealed that the co-expression pattern of nuclear and cytoplasmic HMGB1 in colon cancer cells was inversely associated with the infiltration of both CD3+ and CD45RO+ T cells and the 5-year survival rates of patients with stage IIIB colon cancer. ${ }^{7}$ These data are in accordance with a study with 192 colorectal cancer patients. The HMGB1 expression was positively correlated with tumor invasion, lymph node metastasis, distant metastasis, and Duke's stage of CRC patients. ${ }^{8}$ These data suggest that HMGB1 protein is a potential marker for progression of CRC patients which interacts with tumor infiltrating lymphocytes.

The advantage of adjuvant chemotherapy in patients with stage III colonic cancer has been demonstrated by several studies. ${ }^{9,10}$ In contrast, the real impact of chemotherapy in stage II tumors, that penetrate the subserosa or deeper without involvement of lymph nodes, is still under debate. ${ }^{11-14}$ Mamounas, et al. assessed the relative efficacy of adjuvant chemotherapy according to Dukes' stage in four sequential National Surgical Adjuvant Breast and Bowel Project trials (C-01, C-02, C-03, and C-04). ${ }^{12}$ The authors concluded that independent of the occurrence of prognostic factors, chemotherapy in Dukes B cancer offers a survival benefit in affected patients. However, as the majority of randomized controlled trials found no significant survival improvement by administering chemotherapy after surgery of stage II colonic cancers, current guidelines do not recommend its routine use. ${ }^{15}$ The predictive role of tumor-infiltrating immune cells in these patients needs to be demonstrated in future studies.

\section{REFERENCES}

[1] Galon, J., Costes, A., Sanchez-Cabo, F., Kirilovsky, A., Mlecnik, B., Lagorce-Pages, C., Tosolini, M., Camus, M., Berger, A., Wind, P., et al. Type, density, and location of immune cells within human colorectal tumors predict clinical outcome. Science 2006;313:1960-1964. http://dx.doi.org/10.1126/science.1129139 PMid:17008531

[2] Jochems, C., and Schlom, J. Tumor-infiltrating immune cells and prognosis: the potential link between conventional cancer therapy and immunity. Exp Biol Med (Maywood) 2011;236:567-579. http://dx.doi.org/10.1258/ebm.2011.011007 PMid:21486861

[3] Pages, F., Berger, A., Camus, M., Sanchez-Cabo, F., Costes, A., Molidor, R., Mlecnik, B., Kirilovsky, A., Nilsson, M., Damotte, D., et al. Effector memory T cells, early metastasis, and survival in colorectal cancer. N Engl J Med 2005;353:2654-2666. http://dx.doi.org/10.1056/NEJMoa051424 PMid:16371631

[4] Pages, F., Kirilovsky, A., Mlecnik, B., Asslaber, M., Tosolini, M., Bindea, G., Lagorce, C., Wind, P., Marliot, F., Bruneval, P., et al. In situ cytotoxic and memory T cells predict outcome in patients with early-stage colorectal cancer. J Clin Oncol 2009;27:5944-5951. http://dx.doi.org/10.1200/JCO.2008.19.6147 PMid:19858404

[5] Sinicrope, F.A., Rego, R.L., Ansell, S.M., Knutson, K.L., Foster, N.R., and Sargent, D.J. Intraepithelial effector (CD3+)/regulatory (FoxP3+) Tcell ratio predicts a clinical outcome of human colon carcinoma. Gastroenterology 2009;137:1270-1279. http://dx.doi.org/10.1053/j.gastro.2009.06.053 PMid:19577568 PMCid:2873775

[6] Apetoh, L., Ghiringhelli, F., Tesniere, A., Criollo, A., Ortiz, C., Lidereau, R., Mariette, C., Chaput, N., Mira, J.P., Delaloge, S., et al. The interaction between HMGB1 and TLR4 dictates the outcome of anticancer chemotherapy and radiotherapy. Immunol Rev 2007;220:47-59. http://dx.doi.org/10.1111/j.1600-065X.2007.00573.x PMid:17979839

[7] Peng, R.Q., Wu, X.J., Ding, Y., Li, C.Y., Yu, X.J., Zhang, X., Pan, Z.Z., Wan, D.S., Zheng, L.M., Zeng, Y.X., et al. Co-expression of nuclear and cytoplasmic HMGB1 is inversely associated with infiltration of CD45RO+ T cells and prognosis in patients with stage IIIB colon cancer. BMC Cancer 2010;10:496. http://dx.doi.org/10.1186/1471-2407-10-496 PMid:20846416 PMCid:2949807

[8] Yao, X., Zhao, G., Yang, H., Hong, X., Bie, L., and Liu, G. Overexpression of high-mobility group box 1 correlates with tumor progression and poor prognosis in human colorectal carcinoma. J Cancer Res Clin Oncol 2010;136:677-684. http://dx.doi.org/10.1007/s00432-009-0706-1 PMid:19898867

[9] Andre, T., Boni, C., Mounedji-Boudiaf, L., Navarro, M., Tabernero, J., Hickish, T., Topham, C., Zaninelli, M., Clingan, P., Bridgewater, J., et al. Oxaliplatin, fluorouracil, and leucovorin as adjuvant treatment for colon cancer. N Engl J Med 2004;350:2343-2351. http://dx.doi.org/10.1056/NEJMoa032709 PMid:15175436

[10] Moertel, C.G., Fleming, T.R., Macdonald, J.S., Haller, D.G., Laurie, J.A., Goodman, P.J., Ungerleider, J.S., Emerson, W.A., Tormey, D.C., Glick, J.H., et al. Levamisole and fluorouracil for adjuvant therapy of resected colon carcinoma. N Engl J Med 1990;322:352-358. http://dx.doi.org/10.1056/NEJM199002083220602 PMid:2300087 
[11] International Multicentre Pooled Analysis of B2 Colon Cancer Trials (IMPACT B2) Investigators.Efficacy of adjuvant fluorouracil and folinic acid in B2 colon cancer. J Clin Oncol 1999;17:1356-1363. PMid:10334519

[12] Mamounas, E., Wieand, S., Wolmark, N., Bear, H.D., Atkins, J.N., Song, K., Jones, J., and Rockette, H. Comparative efficacy of adjuvant chemotherapy in patients with Dukes' B versus Dukes' C colon cancer: results from four National Surgical Adjuvant Breast and Bowel Project adjuvant studies (C-01, C-02, C-03, and C-04). J Clin Oncol 1999;17:1349-1355.

PMid:10334518

[13] Moertel, C.G., Fleming, T.R., Macdonald, J.S., Haller, D.G., Laurie, J.A., Tangen, C.M., Ungerleider, J.S., Emerson, W.A., Tormey, D.C., Glick, J.H., et al. Fluorouracil plus levamisole as effective adjuvant therapy after resection of stage III colon carcinoma: a final report. Ann Intern Med 1995;122:321-326.

PMid:7847642

[14] Schippinger, W., Samonigg, H., Schaberl-Moser, R., Greil, R., Thodtmann, R., Tschmelitsch, J., Jagoditsch, M., Steger, G.G., Jakesz, R., Herbst, F., et al. A prospective randomised phase III trial of adjuvant chemotherapy with 5-fluorouracil and leucovorin in patients with stage II colon cancer. Br J Cancer 2007; 97:1021http://dx.doi.org/10.1038/sj.bjc.6604011 PMid:17895886 PMCid:2360441

[15] Benson, A.B., 3rd, Schrag, D., Somerfield, M.R., Cohen, A.M., Figueredo, A.T., Flynn, P.J., Krzyzanowska, M.K., Maroun, J., McAllister, P., Van Cutsem, E., et al. American Society of Clinical Oncology recommendations on adjuvant chemotherapy for stage II colon cancer. J Clin Oncol 2004; 22:3408-3419.

http://dx.doi.org/10.1200/JCO.2004.05.063

PMid:15199089 